\title{
Lis Møller
}

\section{Freud og astetikken}

\section{Psykoanalysen mellem neoklassicisme og romantik}

\begin{abstract}
Psychoanalysis went on to provide a systematic, coherent explanation of Romantic poetics in general. . . . Romantic aesthetics and Psychoanalysis mesh in an almost, to use a suggestive Freudian word, 'uncanny' way.
\end{abstract}

Alvin B. Kernan

Curiously, the effects of the romantic crisis are almost imperceptible in the human sciences around 1900. In their condemnation, explicit or implicit, of the symbol, in their very conception of what the symbol is, Saussure, Lévy-Bruhl and even Freud. . . are neoclassics rather than romantics, contemporaries of Condillac much more than the grandchildren of Moritz, Goethe, or F. Schlegel.

Tzuetan Todorov

\section{I}

Hvis man, som jeg, læser Freuds psykoanalyse som en hermeneutik, der spænder over alle former for semiotisk praksis, fra drøm og neurotisk symptomdannelse, over religion, til kunst og litteratur, og hvis man mener, at "psykoanalysen som helhed er funderet i en symbolteori « (Benveniste, p. 168), så må det være legitimt at ville placere denne symbol- og fortolkningsteori i forhold til en æstetisk, litteraturteoretisk og sprogfilosofisk tradition. Hensigten er naturligvis ikke at forklejne Freuds indsats eller frakende psykoanalysen originalitet, men blot at påpege at Freud har forgængere ikke bare inden for psykologien, psykiatrien og neurofysiologien, men også inden for æstetikken. Citaterne, der indleder min artikel, repræsenterer forsøg på en sådan æstetisk-filosofisk indplacering af psykoanalysen. Hvad mere er: de giver

$K \& K 72(1992), 55-71$ 
to temmelig forskellige - måske endog modsatrettede - bud på, hvilken tradition Freud indskriver sig i. For Alvin B. Kernan betegner psykoanalysen en systematisk udfoldelse og videretænkning af den romantiske æstetik. For Tzvetan Todorov, derimod, er det karakteristisk for Freuds psykoanalyse, at den - ligesom i øvrigt Saussures strukturelle lingvistik - afviser det symbolbegreb, der sammenfatter hele den romantiske æstetik, og griber tilbage til det 18. århundredes neoklassiscistiske retorik og sprogfilosofi. Lad os altså stille sagen på spidsen og spørge: Er psykoanalysen kulminationen af romantisk litteratur og æstetik, eller hører den hjemme i det 18. århundrede? Er Freud romantiker eller er han neoklassiscist - hvilket for Todorov vil sige: »antiromantic“ (Todorov, p. 251)? Må man nødvendigvis vælge mellem Kernan og Todorovs læsning af psykoanalysen, kan det tænkes, at begge har ret, således at modsætningen mellem de to synspunkter er en modsætning i selve Freuds tænkning? Eller er spørgsmålet - romantiker eller neoklassicist? - fra starten galt stillet?

\section{II}

Kernan finder anknytningspunktet mellem romantik og psykoanalyse i den romantiske poetiks opgør med mimesisbegrebet og dens fokusering på (digter)subjektet, »the deep self (Kernan, p. 210), som digtningens primære kilde og genstandsområde. »As Neo-Classicism gave way to Romanticism, at the end of the eighteenth century, « skriver han, "the concern with mimesis and craft, on order and shaping, decreased and the emphasis on poesis and imagination increased « (p. 210). Med romantikken falder forestillingen om den poetiske tekst som imitation, som gengivelse af en faktisk eller ideal natur. "Images, however beautiful, though faithfully copied from nature, and as accurately represented in words, do not themselves characterize the poet, «skriver Coleridge i Biographia Literaria, et af romantikkens centrale æstetiske skrifter. "They become proofs of original genius only as far as they are modified by a predominant passion; or by associated thoughts or images awakened by that passion; or ... when a human and intellectual life is transferred to them from the poet's own spirit《 (Coleridge, p. 272). Poesi er ekspression, en yderligg $\varnothing$ relse af det indre, "the spontaneous overflow of powerful feelings « (Wordsworth 1805, p. 22), eller en inderliggørelse af det ydre, forestillingskraften og lidenskabernes kreative omdannelse af det perciperede objekt. Resulatet af denne forskydning fra mimesis til ekspression og fra natur til subjekt er en æstetik, der (mener Kernan) i stigende grad bliver "dependent on psychology, specially on the concept of the 'imagination' « (p. 210). 
Når skriften bliver ekspressiv og introspektiv, når digtningen reflekterer over sit eget udspring i sindets dybder og afgrunde, bevæger æstetikken sig ind i den dynamisk (dybde)psykologis felt. Den romantiske digters overordentlig stærke indadvendthed - hans s $ø$ gen tilbage til barndommen for at afdække den skabende fantasis kilder, hans dybe fascination af de sjælelige processer og deres mest ekstreme manifestationer - kommer til udtryk som en litteratur, der hævdes at foregribe Freuds opdagelse af det ubevidste. Synspunktet er velkendt. Således ser Lionel Trilling i psykoanalysen kulminationen af den romantiske litteraturs »research into the self « (Trilling, p. 96), mens Henri Ellenberger, under henvisning til romantikernes markante interesse for det ubevidstes artikulation som drøm, geni, galskab, myte og symbol, bestemmer både Freud og Jung som »late epigones of Romanticism « (Ellenberger, p. 200).

Det er da heller ikke vanskeligt at finde eksempler på den forbindelse mellem det romantiske og det psykoanalytiske projekt, som Kernan, Trilling og Ellenberger påpeger. Både digter og psykoanalytiker er, eller forstår sig selv som, opdagelsesrejsende i sindets uopdagede kontinent. »I must tread on shadowy ground, must sink / Deep - « erklærer Wordsworth i The Excursion, hvor han udpeger sit tema, "the Mind of Man«:

»Not Chaos, not

The darkest pit of lowest Erebus,

Nor aught of blinder vacancy - scooped out

By help of dreams, can breed such fear and awe

As fall upon us often when we look

Into our Minds, into the Mind of Man,

My haunt, and the main region of my Song."

(»Prospectus«til The Excursion, 35-41)

Samme interesse for det dybe og skjulte selv finder man hos periodens prosaskribenter og litteraturkritikere. »Boundless as is the domain of man, « skriver Thomas Carlyle, sit is but a small fractional proportion of it that he rules with Consciousness and by Forethought «, »Conscious discourse « er kun en tynd hinde, der dækker "the bottomless, boundless Deep«. Livets rødder strækker sig ned $i$ "the regions of Death and Night " (Carlyle, p. 3-4). I dette mørke og uudgrundelig dyb under bevidsthedens overflade dvæler den vitale kraft, der kommer til udtryk i poesien - eller i drømmen, hvor, med William Hazlitts ord, »the voluntary power is suspended, and things come up upon us as unexpected revelations, which we keep out of our thoughts at other times. ... When awake, we check these rising thoughts, and fancy we have them not. In 
dreams, when we are off our guard, they return securely and unbidden « (Hazlitt 1826, p. 23).

Tanken om, at litteraturen har foregrebet psykoanalysens erkendelser, var ikke fremmed for Freud, der gentagne gange fastslog, at digterne opdagede det ubevidste før han selv. Således priser han i Der Wahn und die Träume in W. Jensens Gradiva digternes »Seelenkunde« og understreger, at de, digterne, $\emptyset$ ser af »Quellen . . . welche wir noch nicht für die Wissenschaft erschlossen haben « (Freud 1907, p. 14). At han med sin bestemmelse af litteraturens emne og kilder anbringer den psykoanalytiske forståelse af digterværket inden for rammerne af romantikkens ekspressive (vs. mimetiske) litteraturteori, synes han derimod ikke at gøre sig klart. Det poetiske kildevæld har sit udspring i digterens eget sind. Digteren skaber ud fra sig selv; han henter sin viden om sjalelivet fra sit eget indre. Om den kreative proces hedder det således, at digteren »richtet seine aufmerksamkeit auf das Unbewusste in seiner eigenen Seele, lauscht den Entwicklungsmöglichkeiten desselben und gestattet ihnen den künstlerischen Ausdruck« (Freud 1907, p. 82). Digtning er introspektion og selv-udtryk.

Freud udpeger selv forholdet mellem værk og liv, mellem værket og kunstnerens intime personlighed, som det undersøgelsesfelt, hvor psykoanalysen og »den æstetiske videnskab« kan mødes (Freud 1913, p. 187). Han placerer hermed den psykoanalytiske kunst- og litteraturinterpretation i forlængelse af romantikkens psykologiske fortolkning, der bestemmer det som sin opgave at forstå "jeden gegebenen Gedankenkomplexus als Lebensmoment eines bestimmten Menschen “ (Schleiermacher 1838, p. 155). Som M. H. Abrams bemærker, er den psykologiske udlægning en uundgåelig konsekvens af romantikkens ekspressive litteraturteori. Mens neoklassicismens doktrin »copy Nature « (Alexander Pope) kun i ringe grad lægger op til en fortolkningspraksis, der søger digteren i værket eller forstår værket i lyset af digterpersonligheden, forholder det sig anderledes med den romantiske æstetik, som netop sætter det poetiske subjekt i centrum. »Ist das Schauen des Geistes in sich selbst die göttliche Quelle alles Bildens und Dichtens, und findet er nur in sich, was er darstellt im unsterblichen Werk: warum soll nicht bei allem Bilden und Dichten, das immer nur ihn darstellt, er auch zurückschauen in sich selbst? « spørger Schleiermacher (Schleiermacher 1800, p. 423). Læeser man den »Geist«, der udtrykker sig som kunst og litteratur, som "[die] persönlichen Eigentïmlichkeit des Verfassers«, »[das] innere Wesen des Schriftstellers« eller »das den Schreibenden bewegende Prinzip « (Schleiermacher 1838, p. 163; p. 164; p. 151), ser man omridset af den form for litteraturbeskæftigelse, som psykoanalysen i første række forbindes med: den forfatter-orienterede analyse, der søger at dechiffrere det, man med en vending lånt fra Schleiermacher kunne 
kalde forfatterens "hemmelige formål”, for herigennem at kaste nyt lys over varket.

For Freud har kunsten og litteraturen som bekendt samme »hemmelige formål« som drømmen, dagdrømmen og barnets leg: opfyldelsen af et (fortrængt - ubevidst, det vil sige infantilt) ønske. »Uopfyldte ønsker er fantasiernes drivkraft, og enhver fantasi er en ønskeopfyldelse, et korrektiv til den utilfredsstillende virkelighed«, skriver han i »Digteren og fantasierne« og tilføjer, at når fantasierne vokser sig store og overmægtige, er betingelserne til stede for en neurose eller psykose« ((Freud 1908, p. 24; p. 25). Kunstneren er »ein introvertierter, der es nicht weit zur Neurose hat «, hedder det i Vorlesungen zur Einführung in die Psychoanalyse. Han er overvældet af »überstarken Triebbedürfnissen«, som realiteten nægter tilfredsstillelse. Som andre utilfredsstillede overfører han derfor sin libido til »die Wunschbildungen seines Phantasielebens, von denen aus der Weg zur Neurose führen könnte« (Freud 1916-17, p. 366). Men, fortsætter Freud, kunstneren finder en vej tilbage til virkeligheden. Han skaber af sine fantasier en ny, symbolsk, realitet: kunstværket, hvorfra også andre kan hente nydelse, trøst og lindring. Værket forløser således ikke blot kunstneren, men også hans publikum. »Det er min opfattelse «, konkluderer Freud, »at den egentlige nydelse ved et digterværk skyldes, at den frigør sjælelige spændinger i os« (Freud 1908, p. 30).

Det uopfyldte $\emptyset$ nske som kreativ drivkraft; forbindelsen mellem digteren og neurotikeren; kunstværkets forløsende og helende funktion: På alle disse punkter anticiperes Freuds litteraturteori af den romantiske astetik. Ligesom psykoanalytikeren fremhæver romantikeren digtningens karakter af ønskeopfyldelse. "We shape things according to our wishes and fancies, without poetry; but poetry is the most emphatical language that can be found for those creations of the mind 'which ecstacy is very cunning in' «, skriver Hazlitt $i$ essayet »On Poetry in General « (Hazlitt, p. 3). Og ligesom psykoanalytikeren understreger romantikeren sammenhængen mellem drøm og digtning (Coleridge) - og mellem digtning og galskab. "Poetry is the lava of the imagination whose eruption prevents an earthquake«, mener Byron. "They say poets never or rarely go mad . . . but are generally so near it that I cannot help thinking rhyme is so far useful in anticipating and preventing the disorder « (citeret efter Abrams, p. 139). Poesi er en "safety-valve, preserving men from actual madness «, skriver John Keble (Keble, p. 55) og tilføjer at »the reader, too, seeks relief through poetry: Poetry properly and truly so called can only be comprehended with a mind full to overflowing, and, consequently, by men whose feelings are so strong that they cannot suppress them, and yet shrink from wholly revealing them « ( $\mathrm{p} 57)$. »Poetry is the indirect expression in words . . . of some overpowering emotion ... the direct indulgence whereof is some- 
how repressed « (Citeret efter Abrams, p. 145).

Den romantiske æstetiks foregribelse af centrale aspekter af Freuds litteraturforståelse er imidlertid mindre væsentlig end det forhold, at den psykoanalytiske hermeneutik som sådan (og her tænkes ikke blot på psykoanalytisk litteraturanalyse) har sin forudsætning i den romantiske hermenutik: den psykologiske udlægning, som Schleiermacher sætter som et supplement til den grammatiske, og hvis mest markante udtryk er den litterære fortolkning. Ganske vist har såvel Paul Ricoeur som Jürgen Habermas fremhævet den afgørende forskel mellem psykoanalysen og den romantiske hermenutik, i.e. Schleiermacher- og Dilthey-traditionen. Således skelner Ricoeur mellem rekonstruktionshermeneutikken og "mistankens hermeneutik « hos Marx, Nietzsche og Freud (Ricoeur 1970), mens Habermas sætter Freuds »dybdehermeneutik « overfor Diltheys fortolkningsteori. "Die Tiefenhermeneutik, die Freud der philologischen Diltheys entgegensetzt, bezieht sich auf Texte, die Selbsttäuschungen des Autors anziegen. Ausser dem manifesten Gehalt . . . dokumentiert sich in solchen Texten der latente Gehalt eines dem Autor selbst unzugänglichen, entfremdeten, ihm gleichwohl zugehörigen Stückes seiner Orientierungen, « skriver Habermas og tilføjer, at »das nichtpathologische Muster eines solchen Textes ist der Traum « (Habermas, pp. 267-68; p. 269).

Det er med andre ord begrebet om det fortrængte, der skiller Freud fra Dilthey. Men bliver Freuds kritiske afbøjning fra den romantiske hermeneutik ikke netop synlig på baggrund af det, der forbinder de to? Både den psykoanalytiske og den romantiske læsning opererer i samme felt og har samme objekt: teksten som psyke og psyken som tekst. Og hvad enten man vil det eller ej, sigter også den psykoanalytiske interpretation mod at rekonstruere en intention, som dybest set bestemmes som forfatterens - også selv om denne måtte være ubevidst for ham. Men spørgsmålet er imidlertid også, om ikke også romantikerne er en slags "mistanke-hermeneutikere«. Ganske vist kan vi ikke uden videre gå ud fra, at romantikernes forestilling om »noget fortrængt « svarer til det psykoanalytiske fortrængningsbegreb, men for romantikeren såvel som for psykoanalytikeren er tekstens subjekt et spaltet subjekt, hvis dybe motivation teksten både skjuler og afslører. Jeg tænker her ikke blot på de romantiske digteres problematisering af det introspektive og autobiografiske projekt, men også på Schleiermacher, der understreger, at fortolkningen må koncentere sig om netop de elementer af teksten, der ikke "går op i « den manifeste intention. »Wenn ... das einzelne nicht alles in der Einheit des Stoffes und der Form aufgeht, und zwar so, dass das Überbelibende eine gemeinsame Beziehung hat, so liegt eben hierin die verborgene Einheit, der heimliche Zweck des Verfassers, « skriver han (Schleiermacher 1838, p. 166) - og foregriber således psykoanalysens læsestrategi. 
Men nu har jeg allerede bevæget mig uden for rammerne af Kernans artikel. Jeg vender tilbage til udgangspositionen: Kernans Freud versus Todorovs.

\section{III}

"Freudian man is . . a symbol-making animal, and so, of course, is the Romantic artist. He does not imitate objective reality but creates out of his imagination new symbolic realities, « skriver Kernan og fortsætter: "the Freudian mind reshapes reality in 'dream work' or in 'primary thought process' in the same way that the Romantic artist constructs his symbols« (p. 212). If $\varnothing$ lge Kernan kan der altså konstateres en forbindelse mellem Freuds bestemmelse af drømmen og dens symbolik på den ene side og det romantiske symbol på den anden. Det er netop forestillingen om en sådan sammenhæng, Todorov gør op med. Freud mangler et specifikt symbolbegreb, hævder Todorov og mener hermed: Freuds psykoanalyse kan ikke rumme et romantisk symbolbegreb. Til forskel fra romantikernes forståelse af symbolet ligger psykoanalysens symbolbegreb inden for rammerne af det lingvistiske tegnbegreb. Eller rettere: Freud har ikke plads til en symbolisering, der rakker ud over tegnets logik. For Freud såvel som for Lévy-Bruhl og Saussure, »neoclassics all«, er symbolet simpelthen "a deviant sign« (p. 291).

Det ovenstående rejser en række spørgsmål: Hvad går det romantiske symbolbegreb nærmere ud på? Hvordan er Freud i sin bestemmelse af symbolet neoklassicist snarere end romantiker? Og hvordan forholder Todorovs forståelse af det romantiske, eller rettere af forholdet mellem neoklassicisme og romantik, sig til Kernans? For at tage det sidste spørgsmål først: For Kernan kan bevægelsen fra neoklassicisme til romantik sammenfattes som den ekspressive kunst-teoris fortrængning af den mimetiske. Det skabende subjekt erstatter naturen som kunstnerisk målestok. »Imagination « - indbildningskraften - sættes i centrum. Todorov valger en anderledes indfaldsvinkel. I hans (semiotiske) perspektiv bestemmes det romantiske gennembrud som æstetikkens fortrængning af retorikken. »Aesthics begins precisely where rhetoric ends, « skriver han. »The substitution of aesthetics for rhetoric coincides, by and large, with the passage from classical to romantic ideology « (p. 111). Ikke at de to synspunkter på forholdet mellem neoklassicisme og romantik på nogen måde behøver at være i modstrid med hinanden, men Todorovs tilgang betegner alligevel en accentforskydning, fra det psykologiske til det semiotiske, der nok kan vise sig betydningsfuld i forbindelse med psykoanalysen.

Når Todorov siger, at æstetikken afløser retorikken, hentyder han ikke blot 
til det forhold, at der med romantikken opstår en litteratur, som nægter at underkaste sig stillærens imperativer. Retorikken falder, fordi selve dens fundament undermineres. Den klasssiske retorik fra Quintillian til Fontanier hviler på det hierarkisk organiserede modsætningspar res og verba, tanke (eller ting) og sprog, hvor res er den styrende og højest vurderede term. Denne modsætning, fastslår Todorov, organiserer i videre perspektiv analysen af ver$b a$, idet den klare diskurs, der lader tanken komme umiddelbart til syne, forholder sig til den besmykkede diskurs, og den egentlige betydning forholder sig til den overførte, figurative, som res forholder sig til verba. Figuren fremstår herved som et ornament, en indpakning, en tankens klædedragt - noget sekundært, udvendigt og afledt. Den retoriske tradition skelner altså mellem tankens bogstavelige udtryk og den figurative overbygning, der tilføjer tanken »some heterogeneous material - feelings, images, ornaments. The existence of the figure rests on the conviction that the two expressions, one with and one without images (feeling and so on) express, as Du Marsais put it, 'the same store of thought' « (p.95). Ricoeur - der med afsat i metaforen sammenfatter hovedpunkterne i den klassiske retorik, »som begynder med de græske sofister og fortsættes med Aristoteles, Cicero og Quintillian, indtil den dør ud i det nittende århundrede« (Ricoeur 1979, p. 166) - formulerer dette synspunkt således: Figuren, som er indsat i stedet for det bogstavelige udtryk, der kunne være brugt på samme sted, betegner ikke nogen »semantisk fornyelse«. »Vi kan oversætte en metafor, d.v.s. genindsætte den bogstavelige mening, som det billedelige ord er en erstatning for. Erstatning plus restitution er faktisk lig nul« (p. 167). For den klassiske retorik har figuren (metaforen) har altså ingen kognitiv værdi; dens domæne er følelserne.

Retorikerne sætter det figurative overfor det bogstavelige. For romantikerne er denne modsætning ubrugelig. I stedet konstitueres med romantikken en ny dikotomi, der ikke er sammenfaldende med den første: modsatningen mellem symbol og allegori, der er en romantisk opfindelse. Symbolet, som det bestemmes i modsætning til allegori, sprænger den klassiske retoriks rammer. I dette symbolbegreb er i følge Todorov hele den romantiske æstetik indeholdt. Om allegori og symbol skriver Goethe i sin opsats »Über die Gegenstände der bildende Kunst « fra 1797: "Das Allegorische unterscheidet sich vom Symbolischen, dass dieses indirekt, jenes direkt bezeichnet « (p. 167). Allegorien betegner direkte, symbolet indirekte. I allegorien bevæger vi os ubesværet fra det betegnende til det betegnede; symbolet, derimod, er uigennemsigtigt. Allegorien står for noget andet. Symbolet står for sig selv og samtidig for noget andet; det både »er« og »betyder«. Allegorien er funktionel og uden værdi i sig selv; den beror på arbitrær konvention. Symbolet er naturligt. Allegorien udtrykker det, der kan udsiges på anden vis; symbolet udtrykker det 
uudsigelige. I symbolet, skriver Goethe, transformeres ideen til billede på en sådan måde, "dass die Idee im Bild immer unendlich wirksam und unerreichbar bleibt und, selbst in allen Sprachen ausgesprochen, doch unaussprechlich bliebe « (Nachlass«, p. 638). Symbolet er således ikke blot flertydigt, men uudtømmeligt. Symbolet "provokes an unending task of interpretation; the allegory is intentional, and can be understood without 'remainder' " (Todorov, p. 207).

Det er nu Todorovs pointe, at Freud ikke blot $i k k e$ er romantiker (idet hans forståelse af symbolet afviger fra den romantiske æstetiks), men at han er neoklassicist, for så vidt som han - uden selv at vide det - genopdager den retoriske tradition, der gik i glemmebogen med romantikken. Todorov ligger her på linie med Benveniste, som i artiklen »Bemærkninger om sprogets funktion i Freuds analyse « konstaterer, at alt i psykoanalysen er »formidlet af sprog « at psykoanalysens objekt altså er af diskursiv art - men at det, der kendetegner det ubevidste(s) sprog, er dets »stilistiske virkemidler« (Benveniste, p. 158; p. 176). Det ubevidste taler i troper. Som Todorov udtrykker det: »The symbolic mechanism that Freud has described lacks specificity; the operations that he identifies are simply those of any linguistic symbolism, as they were inventoried, most notably, by the rhetorical tradition « (p. 248).

Todorov baserer sin konklusion på en læsning af Freuds afhandling om vitsen, Der Witz und seine Beziehung zum Unbewussten. En særdeles velegnet tekst til formålet. Ikke blot fordi Freud med sin klassifikatoriske opregning af de forskellige vits-mekanismer - fortætning med dannelse af blandingsord; fortætning med modifikation; inversion; dobbeltbetydning; forskydning; allusion (for blot at nævne nogle få eksempler) - tydeligvis genopfinder et helt katalog af troper og figurer. Men først og fremmest fordi selve teorien om vitsen hviler på den klassiske res/verba dikotomi. Hvad er det, der gør en vits til en vits? spørger Freud - og konstaterer omgående, at »der Witzcharacter . . . nicht dem Gedanken anhaftet « men ligger »in der Form, im Wortlaut seines Ausdruckes« dvs. i vitsens »Wort- oder Ausdruckstechnik (Freud 1905, p. 21). Denne modsætning mellem »tanke« og »verbal udtryksform « eller »teknik « styrer hele afhandlingen. På baggrund af den betragtning, at det er muligt at omskrive en vits, så dens evne til at fremkalde latter forsvinder, men uden at dens tankeindhold herved modificeres, »reducerer « Freud en række vitser til en verbal form, der lader tanken komme umiddelbart til syne. I sammenligningen mellem den originale og den reducerede vits isoleres vits-teknikken, der nu kan unders $\varnothing$ ges særskilt. Resultatet af denne unders $\varnothing$ gelse er det ovennævnte »old catalogue of tropes " (Todorov, p. 248).

Vitsens formål er at fremkalde latter - lyst. Og dennne lyst er knyttet til den særlige vits-form, som Freud betegnende nok kalder vitsens »Entkleidung«, 
og som han holder skarpt adskilt fra vitsens »substans«, dens »Gedankengehalt « (p. 88). Men ikke alle vitser er lige morsomme. Og eftersom alle i princippet betjener sig af samme teknikker, dvs. af samme sæt af troper og figurer, må nogle råde over lystkilder, som andre ikke har adgang til - lystkilder, der må henføres til tanken og ikke til den sproglige iklædning. Freud skelner i denne forbindelse mellem den harmløse vits og tendensvitsen, den vits der har et formål, og ender med at konstatere, at tendensvitsen artikulerer en tanke, der i sin umiddelbare form ville vække modstand, men som netop den vittige indpakning giver os mulighed for nyde. En mindre lyst (knyttet til formen) giver her adgang til en større og dybere lyst (knyttet til tanken), som ellers ville være spærret. Vi ser således, at Freud ikke bare genopliver den klassiske retorik, men også fornyr den. Vitsens særlige udtryksform, dens troper og figurer, er ikke blot ornament, men har tillige den funktion, at den momentant ophæver fortrængningen. Hvilket imidlertid ikke ændrer på det forhold, at Freud med sin hierarkisk organiserede distinktion mellem tanke og sprogligt udtryk og mellem direkte udtryk og figurativ iklædning forbliver inden for rammerne af den retoriske tradition.

Ligesom overvejelserne om litteratur og kreativitet ikke er et vedhæng, men en integreret del af af Freuds tænkning, således er teorien om vitsen heller ikke at forstå som en isoleret provins i psykoanalysen. Afhandlingen om vitsen (som i øvrigt lægger op til »Digteren og fantasierne«) er en direkte udløber af Drømmetydning, og Freud lægger stor vægt på at påvise sammenhængen mellem vitsen og drømmens udtryksform. Todorovs læsning af Der Witz und seine Beziehung zum Unbewussten dækker således også Drømmetydning. Den afgørende distinktion i dette værk mellem manifest og latent drøm - som bestemmes som »to fremstillinger af det samme indhold«, hvor den latente drøm (drømmetankerne) er »uden videre forståelige for os«, mens den manifeste er en »overføring af drømmetankerne til en anden udtryksmåde« (Freud 1900, p. 233) - synes uden videre at kunne indpasses i den retoriske tradition. I forlængelse heraf bliver det også klart, hvorfor Todorov må hævde en afgørende forskel mellem romantikernes forståelse af symbolet og Freuds tilgang til drømmens symbolik. Ikke blot synes Freud i Drømmetydning at ville reservere betegnelsen "symbol « til de såkaldte faste symboler - den symbolik, der »ikke [er] speciel for drømme, men tilhører det ubevidste forestillingsliv, navnlig hos det jævne folk « (p. 284). »Let us . . note in passing that Freud's use of the word 'symbol' is opposed to that of the romantics (for whom fixed meaning corresponds rather to allegory)«, kommenterer Todorov (p. 251). Når Freud i følge Todorov er »antiromantic «, skyldes det imidlertid først og fremmest, at »he affirms that latent thoughts are in no way different from any other thoughts, in spite of their symbolic mode of transmission: for the romantics, 
on the contrary, the symbol's content differs from that of the sign, and that is why the symbol is untranslatable « (p. 251).

For romantikerne giver symbolet en indsigt, der ikke kan nåes ad anden vej. Symbolet artikulerer en sandhed, der ikke kan udtrykkes på anden vis. Symbolet er således uoversætteligt og kan ikke udtømmes af nogen fortolkning. Anderledes forholder det sig med Freuds forståelse af drømmen og dens symbolisering, siger Todorov. I Drømmetydning fremstilles fortolkningen som symboliseringens (drømmearbejdets) parallelle, men omvendte proces. Hvor drømmearbejdet betegner en »oversættelse « af de latente drømmetanker til drømmens figurative udtryksform, fremstår tolkningen, drømmetydningen, som en genindsættelse af det non-figurative udtryk. Drømmen må »overføres til drømmetankernes sprog « (Freud 1900, p. 233). Og selv om Freud understreger, at drømmen kan have flere betydninger, bekræfter han ifølge Todorov i sidste instans muligheden for restløs fortolkning. Freud sætter en grænse for flertydigheden, skriver Todorov: "there exist ultimate symbolized elements, which are no longer convertible in turn into symbolizers « (p. 253). Psykoanalytisk fortolkning kan derfor bestemmes som »finalist interpretation« (p. 254).

\section{IV}

Lad mig stoppe op og gøre status. Som det gerne skulle være fremgået, kan såvel Kernan som Todorov dokumentere deres synspunkter ud fra Freuds tekst, og i den forstand kan begge siges at få ret. Men samtidig står det klart, at Todorovs Freud-læsning ikke blot udgør et supplement til Kernans. Måske er det for stærkt at sige, at Todorov med sin analyse af den symbol-teori, som psykoanalysen hviler på, reducerer den påståede forbindelse mellem psykoanalysen og den romantiske æstetik til en overfladisk lighed. Men i hvertfald: det synes, som om Freuds romantiske position undermineres af det, Todorov kalder psykoanalysens anti-romantiske symbolbegreb. Det er da også betegnende, at Kernan netop med hensyn til symbolet må gøre indrømmelser til Todorovs synspunkt (som han i parentes bemærket ikke synes at kende til, ligesom Todorov heller ikke kender Kernans artikel): Godt nok består der en nær forbindelse mellem drømmearbejdet og det romantiske symbol, men, siger Kernan henimod slutningen af sin artikel, »Romantic aesthetics and Psychoanalysis ... are ultimately in conflict over the meaning of the projected image, the symbol or art work. For Psychoanalysis it remains a distorted and disguised form of a simpler, more fundamental truth« (p. 215) - en sandhed, som alene analytikeren har nøglen til, og som bedst udtrykkes $\mathrm{i}$ »classically simple denotative language« (p. 214). 
Selv om Kernan fastholder sit grundsynspunkt om en »nærmest uhyggelig « overensstemmelse mellem psykoanalysen og den romantiske æstetik, synes Todorov således at få det sidste ord: Freud er - dybest set - »neoclassic rather than romantic«. Men vi er ikke færdige endnu. For i samme øjeblik som Kernan (i den af mig iscenesatte diskussion) nærmer sig Todorovs synspunkt, indtager denne et standpunkt, der ikke ligger så fjernt fra Kernans udgangspunkt. Freud er måske alligevel - dybest set - romantiker. Ganske vist siger Todorov det ikke helt så direkte. $\mathrm{Og}$ ganske vist er den romantiske position, der kommer til syne under, eller $i$, den neoklassicistiske ikke helt sammenfaldende med »det romantiske «, som Todorov har defineret det ovenfor. Men meningen er for mig at se ikke til at tage fejl af. Freuds neoklassicistiske position undergraves indefra. Men måske skulle vi helst undgå termen »neoklassicistisk «. For selv om det fortsat giver mening i forhold til Todorovs argumentation at tale om det klassiske kontra det romantiske, så viser det sig i stigende grad vanskeligt at fastholde forestillingen om en modsætning mellem på den ene side romantisk æstetik og på den anden side de 1700-tals tænkere, som Todorov forsyner med etiketten »neoclassics«. Det 18 . århundredes sprogfilosofi åbnes mod romantikken, og vice versa.

Lad os først undersøge, hvorledes den forestilling om figuration og fortolkning, som Todorov har draget frem i lyset, problematiseres af Freuds egen tekst. Pladsen tillader desværre ikke en indgående læsning, så jeg skal begrænse mig til at opregne nogle enkeltpunkter: Ser vi først på Drømmetydning, er det ganske vist rigtigt, at Freud her fremstiller drømmen som en symbolisering, der i tolkningen restløst kan oversættes til drømmetankernes ligefremme udtryksmåde. Alligevel siger Freud, at »man i grunden aldrig er sikker på at have tydet en drøm fuldstændigt« (Freud 1900, p. 234). Drømmetydningen havner nødvendigvis i en apori: "I selv de bedst tydede drømme må man tit lade et sted forblive uopklaret “, skriver han. »Dette er da drømmens navle det sted, hvor den er fastgjort til det ukendte «. Dr $\emptyset$ mmmetankerne forgrener sig i alle retninger, og fra et tættere sted i dette netværk "rejser drømmeønsket sig . . som svampen af myceliet« (p. 416). Og videre: Godt nok er det sandt, at Freud gentagne gange bekræfter muligheden for uden meningstab at omsætte f.eks. den litterære teksts figurative sprog til psykoanalysens begrebssprog (om Jensens Gradiva siger han således, at han har gengivet romanen »mit den technischen Ausdrücken unserer Wissenschaft “(Freud 1907, p. 44)). Men samtidig gør han det andetsteds klart, at dette begrebssprog i sig selv er et billedsprog. Således $\mathrm{i}$ »Hinsides lystprincippet «: »vi er nødt til at arbejde med videnskabelige termer, det vil sige med psykologiens (eller mere præcist: dybdepsykologiens) eget billedsprog. Ellers kunne vi slet ikke beskrive de tilsvarende processer, ja vi ville slet ikke have opfattet dem«, skriver Freud og 
tilføjer: »Manglerne ved vor beskrivelse ville sandsynligvis forsvinde, hvis vi i stedet for de psykologiske termer med det samme kunne indsætte de fysiologiske eller kemiske. Disse tilhører ganske vist også kun et billedsprog . . « (Freud 1920, p. 63).

Det ovenstående peger på en dobbelthed i Freuds argumentation. På den ene side bekræfter han Kernans teori om, at psykoanalysen ser digterværket (og drømmen) som en forvansket fremstilling af en »truth «, der bedst udtrykkes i »classically simple denotative language«. På den anden side dementerer den psykoanalytiske fortolkningspraksis denne opfattelse, ligesom forestillingen om »classically simple denotative language « problematiseres, idet begrebssproget fremstilles som et sæt af metaforer, hvis oprindelse er gået $\mathbf{i}$ glemmebogen. Går man nu til Der Witz und seine Beziehung zum Unbewussten, som jo er den tekst, Todorov diskuterer mest indgående, tegner der sig en tilsvarende ambivalens. Freud forsøger her som nævnt at bestemme vitsens forskellige teknikker og følger således i den klassiske retoriks fodspor. Men idet den rent klassifikatoriske bestræbelse suppleres med en historiserende, trader brudfladerne i Freuds argumentation frem. Om vitsens psyko-genese hedder det, at en (førbevidst) tanke overgives til ubevidst bearbejning. En tanke iføres vitsens klædedragt. Men samtidig gøres det klart, at vitsarbejdet ligesom drømmearbejdet betjener sig af en for det psykiske apparat primær funktionsmodus - primærprocessen. På den ene side fremstilles det figurative altså som sekundært og afledt. På den anden side bestemmes det som primært og oprindeligt, og netop dette forhold giver Freud anledning til at spekulere over, om ikke vitsen med tanken som påskud giver os mulighed for uhindret at nyde det spil med ordene, som barnet henter så stor lyst fra, men som fornuften tvinger os til at give afkald på. Resultatet af disse spekulationer er en bemærkelsesværdig omvending af den klassiske retoriks klædningsmetafor. Således hedder det f.eks.: "Es war dem Witz das eine Mal gelungen, sich . . . im Ausdruck eines Wertvollen Gedankens einzuschmuggeln« (Freud 1905, p. 190). Den tilgrundliggende modsætning mellem tanke og teknik og mellem substans (indre) og klædedragt (ydre) er intakt, men hele konstruktionen vakler, idet der vendes op og ned på hierarkiet, og tanken bliver den form, den klædedragt, som teknikken kan »snige sig ind $\mathrm{i} \ll$.

I sin diskussion af afhandlingen om vitsen kommenterer Todorov psykoanalysens teori om ordspillet, men vælger at læse Freuds holdning som et udslag af ekstrem rationalisme. Alt det, der ikke svarer til det klassiske begreb om mening og logik, bliver i psykoanalysen til »non-sense « og lægges over på »de andre«, barnet og den gale, mener Todorov. Han overser herved, at det netop er Freuds behandling af nonsens og ordspil, der (som vist ovenfor) destabiliserer den retoriske tradition, som Der Witz hævdes at hvile på. Men 
Todorovs argumentation får en ny dimension, idet han efterfølgende foreslår, at Freuds forståelse af vitsteknik, primærprocestænkning og barnets leg med ord må ses i sammenhæng med (det 18. århundredes) teorier om primitivt sprog og sprogets oprindelse. For ifølge Todorov røber disse teorier om det oprindelige sprog nemlig en »implicit knowledge of the symbol as it exists in the present « (p. 227) - altså en tilnærmelse til det romantiske.

Sammenkædningen af psykoanalysens teori om primærprocessen og spekulationerne om sprogets oprindelse er relevant, ikke mindst fordi Freud selv er inde på samme tankegang. Som bekendt mente Freud, at der måtte kunne påvises en sammenhæng mellem primærprocestænkning og primitivt sprog, og han opgav aldrig håbet om, at sprogvidenskaben ville komme ham til hjælp på dette punkt. I artiklen »Über den Gegensinn der Urworte " fra 1913 knytter han således sin teori om drømmearbejdet til K. Abels afhandling om ordenes udvikling; hos Abel mente han at have fundet belæg for forestillingen om, at drømmens sprog er et »ursprog «. Men tanken om, at det ubevidstes sprog er et arkaisk sprog går helt tilbage til Studien über Hysterie, hvor Freud konstaterer, at det hysteriske symptom kan forståes som en re-vitalisering af en død metafor - hvilket får ham til at udkaste den hypotese, at hysteriens symbolisering er en genopdagelse af en oprindelig udtryksmåde.

Det har længe været god tone at afvise Freuds spekulationer om primærprocestænkning og ursprog som den rene pseudo-videnskab - hvilket de også er i filologisk henseende. Hvis man imidlertid (som Todorov foreslår) sætter disse spekulationer i forbindelse med det 18 . århundredes teorier om sprogets oprindelse, fremstår de i et noget andet lys. Som Hans Aaarsleff bemærker, blev det 18. århundredes diskussion af spørgsmålet om sprogets oprindelse systematisk misforstået af det 19. århundredes filologisk orienterede sprogvidenskab, der overså, at hensigten ikke var at levere en »historical and factual explanation of states of language in the past « (Aarsleff, p. 163). For det 18. århundredes sprogfilosofi er "ursproget« således ikke at opfatte som et historisk faktum, men har karakter af en hypotetisk konstruktion til forståelse af sproget - på linie med f.eks. Freuds »urhorde«, der er en teoretisk konstruktion til forståelse af $\emptyset$ dipus-komplekset. 1700-tallets spekulationer om sprogets oprindelse er teorier om sprogets natur. Og hvad mere er: disse teorier anfægter på afgørende vis den klassiske retoriks grundlag.

Den klassiske retoriks begyndende sammenbrud manifesterer sig som en krise inden for selve den retoriske disciplin, siger Todorov og påpeger, at det 18. århundredes retorikere i stigende grad har vanskeligheder ved at fastholde en norm, som det figurative skulle være en afvigelse fra, ligesom de heller ikke kan fastholde modsætningen mellem »tanke « og »følelse «. Diskussionen af spørgsmålet om sprogets oprindelse er en del af dette billede. Fra Vico over 
Condillac (Essai sur l'origine des connaissances humaines) til Rousseau er grundsynspunktet det samme: Det første sprog er et lidenskabernes udtryk. Følelsernes sprog er et billedsprog - altså er sproget oprindeligt figurativt, hvilket igen vil sige: poesien kom før begrebssproget. De ældste sprog er »vives et figurées, « skriver Rousseau. »Comme les premiers motifs qui firent parler l'homme furent des passions, ses premières expressions furent des tropes. Le langage figuré fut le premier à naître, le sens propre fut trouvé le dernier« (Rousseau, p. 505). Den bogstavelige betydning er afledt af den figurative, og ikke omvendt. At dette synspunkt er at forstå som en markant kritik af den klassiske retoriks præmisser fremgår klart af Vico: »All the tropes ... which have hitherto been considered ingenious inventions of writers, were necessary modes of expression of all the first poetic nations", skriver han. "And here begins the overthrow of two common errors of the grammarians: that prose speech is proper speech, and poetic improper; and that prose speech came first and afterward speech in verse « (Vico, p. 131).

Det 18. århundredes behandling af spørgsmålet om sprogets oprindelse er ikke blot et moment i den klassiske retoriks sammenbrud. Som de ovenfor citerede passager antyder, udg $\varnothing \mathrm{r}$ Vico, Condillac og Rousseau samtidig en væsentlig forudsætning for den romantiske (ekspressive) æstetik. I et essay, der diskuterer forbindelsen mellem Condillac og Wordsworth, skriver Aarsleff bl.a.: "Wordsworth rejected the poetic practice of and the dominant theory of the last century, but he built his own critical theory on the philosophy of the same century that had given language a central place in our understanding of the ways of knowing, communication, and the potentialities of expression " (Aarsleff, p. 373). Og videre: »The source [of romantic aesthetics at large] lies in the philosophy that is usually dismissed as antithetical to romanticism « (p. 377). At det 18. århundredes teori om sproget som naturligt figurativt opsuges i den romantiske æstetik og fungerer som et centralt element i forståelsen af det poetiske sprog fremgår af Wordsworths »Preface til Lyrical Ballads, hvor det $\mathrm{i}$ forbindelse med diskussionen af $\gg$ the language of Poetry « hedder: »if the poet's subject be judiciously chosen it will naturally . . . lead him to passions the language of which . . . must necessarily be . . . alive with meta-phors and figures « (Wordsworth 1805, p. 30). Fra samme forord henter Kernan den berømte definition af digtning som "spontaneous overflow of powerful feelings «, der for ham sammenfatter romantikkens ekspressive litteraturteori. Således mødes romantikken og det 18. århundredes sprogfilosofi.

Ringen er hermed sluttet. Den romantiske forestilling om litteratur som ekspression, som udtryk for det indre, var udgangspunktet for Kernans sammenkadning af psykoanalysen og den romantiske æstetik. Via bl.a. Condillac - Freuds »samtidige«, ifølge Todorov - er vi nu tilbage ved Wordsworth og 
romantikken. Imidlertid er vi ikke bare tilbage, hvor vi begyndte; slutpunktet er forskudt $\mathrm{i}$ forhold til begyndelsespunktet. Mens Kernan i sin bestemmelse af det romantiske alene fokuserede på den romantiske litteratur og æstetiks dybdepsykologiske dimension, lægger Aarsleff med sin bestemmelse af romantikkens "sources « vægten et andet sted: "For both Condillac and Wordsworth language is the central problem of literary theory and poetic art" « (Aarsleff, p. 378, min fremhavelse). Det er i dette dybdepsykologiske $o g$ semiotiske felt, Freud placerer sig. Psykoanalysen er en »psychologized rhetoric«, mener Harold Bloom (Bloom, p. 389). Samme konklusion når Todorov for så vidt frem til i sin semiotiske læsning af Freud. Min konklusion skal være, at denne »psykologiserede retorik « har både klassiske og romantiske rødder. Den er ikke bare at forstå som et genoptryk af »the rhetorical tradition « (Todorov, p. 248), men er samtidig et kritisk opgør med grundlaget for denne tradition - og dermed en anden retorik end den, der gik i glemmebogen.

\section{Referencer:}

Aarsleff, Hans, From Locke to Saussure: Essays on the Study of Language and Intellectual History (Minneapolis: University of Minnesota Press, 1982).

Abrams, M. H., The Mirror and the Lamp: Romantic Theory and the Critical Tradition (Oxford: Oxford University Press, 1953).

Benveniste, Emile, »Bemarkninger om sprogets funktion i Freuds analyse « i Psykoanalyse, litteratur, tekstteori, ed. Jørgen Dines Johansen, bd. I (København: Borgen, 1977).

Bloom, Harold, Wallace Stevens: The Poems of Our Climate (Ithaca: Cornell University Press, 1976).

Carlyle, Thomas, »Characteristics« (1831) i Critical and Miscellaneous Essays bd. 3 (London: Chapman and Hall, 1899).

Coleridge, Samuel Taylor, Biographia Literaria i Selected Poetry and Prose of Coleridge, ed. Donald A. Stauffer (Random House, 1951).

Condillac, Étienne de, Essai sur l'origine des connaissances humaines i Oeuvres complètes bd. 1 (Geneve: Slatkine Reprints, 1970).

Ellenberger, Henri F, The Discovery of the Unconscious: The History and Evolution of Dynamic Psychiatry (New York: Basic Books: 1970).

Freud, Sigmund (1900), Drømmetydning (København: Hans Reitzel, 1974).

- (1905), Der Witz und seine Beziehung zum Unbewussten, Studienausgabe bd. 4 (Frankfurt am Main: Fischer 1969-79).

- (1907), Der Wahn und die Träume i W. Jensens Gradiva, Studienausgabe bd. 10.

- (1908), »Digteren og fantasierne « i Psykoanalyse, litteratur, tekstteori bd. 1.

- (1910) »Über den Gegensinn der Urworte«, Gesammelte Werke bd. 8 (Frankfurt am Main: Fischer, 1943).

- (1913), »Das Interesse an der psychoanalyse«, Gesammelte Werke bd. 8.

- (1916-17), Vorlesungen zur Einführung in die Psychoanalyse, Studienausgabe bd.1. 
- (1920), »Hinsides lystprincippet« i Metapsykologi, ed. Andkjær Olsen og Køppe, bd. 1 (København: Reitzel, 1976).

Goethe, Johann Wolfgang (1797), »Über die Gegenstände der bildenden Kunst « $\mathrm{i}$ Goethe: Berliner Ausgabe bd. 19 (Berlin: Aufbau Verlag, 1985).

—, "Aus dem Nachlass « i Goethe bd. 18.

Habermas, Jürgen, Erkenntnis und Interesse (Frankfurt am Main: Suhrkamp, 1973).

Hazlitt, William (1818), »On poetry in General« i The Collected Works of William Hazlitt bd. 5 (New York, 1902).

- (1826), »On Dreams i Collected Works bd. 7 (New York, 1903).

Keble, John, Lectures on Poetry 1832-184I bd. I (Oxford, 1912).

Kernan, Alvin B., "Romantic Aesthetics and Freudian Psychoanalysis«, International Review of Psycho-Analysis (1979) 6.

Ricoeur, Paul (1970), Freud and Philosophy: An Essay on Interpretation (New Haven: Yale University Press).

— (1979), Fortolkningsteori (København: Vinten).

Rousseau, Jean-Jacques, Essai sur l'origine des langues (Paris: Bibliothèque du Graphe, 1976).

Schleiermacher, Friedrich (1800), »Monologen« i Schleiermachers Werke bd. 4 (Scientia Verlag, 1967).

- (1838), »Hermeneutik« i Werke, bd. 4.

Todorov, Tzvetan, Theories of the Symbol (Ithaca: Cornell University Press, 1982).

Fransk originaludgave: Théories du symbole (Paris: Seuil, 1977).

Trilling, Lionel, "Freud and Literature « i Freud: A Collection of Critical Essays, ed. Perry Meisel (Englewood Cliffs: Prentice-Hall, 1981).

Vico, Giambattista, The New Science (Ithaca: Cornell University Press, 1984).

Wordsworth, William, The Excursion i Poems, Volume II, ed. John O. Hayden (Harmondsworth: Penguin, 1977).

- (1805), Lyrical Ballads (London: Macdonald \& Evans, 1976). 
